\title{
A BROKEN LANDSCAPE
}

'A Broken Landscape', an exhibition of photographs by Gideon Mendel at the South African National Gallery, Cape Town, closed on Saturday 13 April 2002. Mr Justice Edwin Cameron, of the Supreme Court of Appeal, gave the following address.

This exhibition has been a remarkable event. Its presence here represents a major commitment by the South African National Gallery to people living with HIV and AIDS. The work on display itself shows deep commitment.

What does it mean to say that an artist (or an art gallery) 'shows commitment'? It means that he or she brings not only an engagement to the subject of the display, but an involvement in it that transcends mere observation or representation.

This is plain from Gideon Mendel's 'A Broken Landscape'. The photographer has shown an imaginative and respectful engagement with his topic. But he has done infinitely more than that. He has aligned himself unmistakably with the reality that confronts his subjects and those around them.

His depiction of that reality is astonishing in its power, in its graphic truth, in its respectful distance and in its searing intimacy.

He places before us images that shock us with their force and closeness. The reason is that he has involved himself with the extremity of his subjects' struggle, who are at the very edge of life. He shows us the inexpressible complexity, the terrible simplicity, and the dignity of that state.

In achieving this, neither the artist nor his exhibition has been static. As events have moved, he has included them - the court battle about the provision of antiretroviral medication to pregnant mothers, the claim to life of those who for the first time are now gaining access to longerterm drug therapy.

In all of this the artist is depicting a truth. But his work also makes a call to action. The exhibition challenges those who view it to take a position on the lives and the deaths of those it represents.

That call to action echoes the most urgent current question in our national life. It is true that we have a 'crisis of AIDS' in our country. On the one hand that crisis is one of illness and suffering and dying - dying on a larger scale and in conspicuously different patterns from before; on a scale globally that dwarfs any disease or epidemic the world has known for more than six centuries. On the other hand that crisis is one of leadership and management - a challenge to every person with power and resources and skills to use them to alleviate and obviate suffering and death on this scale.

But most importantly, and most tragically, in our nation that crisis is also one of truth-telling. The most fundamental crisis in the AIDS epidemic is our nation's struggle to identify and confront and act on the truth about AIDS.

This third crisis in AIDS had been engendered by those in our country who deny the facts about AIDS. There are those who deny that AIDS has introduced disturbingly new patterns of disease and dying to our sub-continent. They deny that these new patterns are the result of an infectious agent, a virus, one that is mostly sexually transmitted; one that enters the human body, and attacks the immune system, and destroys it through retroviral activity, rendering it vulnerable to attack by a host of infections.

Crucially, these deniers also reject the most signal truth in the AIDS epidemic. This is that the destructive activity of the virus within the human body can be completely contained by carefully administered and properly monitored antiretroviral medications.

The deniers revile those speaking the truth about AIDS for engaging in 'scare-mongering'. They attack them as agents of an 'omnipotent apparatus' engaged in 'a massive political-commercial campaign to promote antiretroviral drugs.' They condemn those speaking the truth about AIDS for a supposed campaign 'to medicalise poverty and underdevelopment.'

They depict the facts about AIDS as a monstrous plot against Africans because they are black. In this the denial of AIDS represents the ultimate relic of apartheid's racially imposed consciousness, and the deniers achieve the ultimate victory of the apartheid mindset.

The cost is immeasurable. The acts and words of the deniers have at every level paralysed our national response to the epidemic. They have confused our planning and befuddled our strategies. They have confounded our 
insights, sapped our energies and dispirited our determination to act.

And, most significantly, they have silenced all too many voices among those who are experiencing the epidemic in their own bodies and their own families and in their own communities. The deniers have re-created shame, and reimposed silence, in an epidemic where the struggle for twenty years has been to create voices and to defeat shame.

The denial of the facts about AIDS is not only an outrage against the truth. It is a profound insult to those South Africans who are living with and dying from the effects of the virus. They deny us the dignity of our suffering. They deny us the dignity of our struggle for life against the workings of a viral agent.

Most importantly, they deny us the dignity of the truth, and the power and hope, and the opportunities for action, that acceptance of the truth brings.

In countless villages and townships and cities and settlements in South Africa, where the virus is taking its toll of health and life among our people, the terrible truth about AIDS is being born and lived and died. Our people are being born, are living with, and dying from that truth. They are living that truth in the rising fevers, the wasting of flesh and the slow, agonised cessation of bodily functions that result from the virus.

Their suffering is being increased and is being prolonged incalculably by the deniers.

But, as we have seen today, from the terrible grief of those affected by the virus a terrible determination arises: a determination to defeat untruth and misrepresentation and distortion, and to assert hope.

That is the ultimate significance of the unforgettable images of this exhibition: that untruth and inaction are the greatest crimes of all. Let us take an angry inspiration, and a deep determination, from that.

REFERENCE

1. Hongwane C. Caravans, cats, geese, foot \& mouth and statistics - HIV/AIDS and the struggle for the humanisation of the African. ANC document, distributed April 2002.

\section{FOCUS}

\section{HIV/AIDS profile in the provinces of South Africa, 2002}

A booklet entitled HIV/AIDS Profile in the Provinces of South Africa: Indicators for 2002 has recently been released. It makes provincial trends and statistics on the HIV/AIDS epidemic available to government officials at all levels, as well as to business people, non-governmental organisations (NGOs) and the public. The report gives readers a sense of the magnitude of the numbers involved, and will allow them to benchmark other information about the epidemic as it becomes available.

The booklet can be downloaded from www.mrc.ac.za or www.assa.org.za/aidsmodel.asp or www.commerce.uct. ac.za/care, and is also available from the University of Cape Town (UCT)'s Centre for Actuarial Research at R30 per copy (tel. (021) 650-2475).

The estimates provided are not new - in fact, they have been available for the last year on the Actuarial Society of South Africa's website - but it is the first time they have been compiled into one publication for ease of access.

The indicators are based on a model constructed by the Actuarial Society of South Africa (ASSA). While there is always a degree of uncertainty surrounding such estimates, models can provide an invaluable tool for giving a sense of possible future scenarios. The ASSA model is continuously being improved as more data become available and our understanding of the dynamics of the epidemic improve.

Some of the information available in the report:

졸 The extent of the epidemic, with 6,5 million people ( $14,2 \%$ of the population) infected with HIV by July 2002.

Of these, over 95\% (6.1 million) are in the age group 18 - 64 years (labour force age).

The prevalence is highest (25.9\%) among young women of childbearing age - this, in turn, has implications in terms of numbers of orphans.

The prevalence of HIVIAIDS (among all ages) in each of the provinces is as follows:

$\begin{array}{llll}\text { KwaZulu-Natal } & 18.4 \% & \text { Eastern Cape } & 11.3 \% \\ \text { Free State } & 16.7 \% & \text { Limpopo } & 11.0 \% \\ \text { Mpumalanga } & 16.5 \% & \text { Northern Cape } 7.9 \% \\ \text { Gauteng } & 16.0 \% & \text { Western Cape } & 4.2 \% \\ \text { North West } & 15.1 \% & & \end{array}$

